\title{
Molecular characterization of accessions of Cratylia argentea (Camaratuba) using ISSR markers
}

\author{
G.A. Luz ${ }^{1}$, S.O. Gomes ${ }^{1}$, R.B. Araujo Neto ${ }^{2}$, M.S.C.B. Nascimento ${ }^{2}$ and \\ P.S.C. Lima ${ }^{2}$ \\ 'Laboratório de Biologia Molecular, Centro de Ciências Agrárias, \\ Universidade Federal do Piauí, Teresina, PI, Brasil \\ ${ }^{2}$ Laboratório de Biologia Molecular, Embrapa Meio-Norte, Teresina, PI, Brasil \\ Corresponding author: P.S.C. Lima \\ E-mail: paulo.costa-lima@embrapa.br \\ Genet. Mol. Res. 14 (4): 15242-15248 (2015) \\ Received October 5, 2015 \\ Accepted November 13, 2015 \\ Published November 25, 2015 \\ DOI http://dx.doi.org/10.4238/2015.November.25.12
}

\begin{abstract}
Cratylia argentea (Desv.) Kuntze (Fabaceae) is a droughttolerant, perennial legume found primarily in Brazil, Bolivia, and Peru. The shrub is well adapted to acid soils and exhibits high productivity and nutritional value, characteristics that would favor its use as a dry season animal forage supplement in semiarid regions. In plant improvement programs, the production of elite hybrids with superior traits is generally achieved by crossing parents that exhibit the highest level of genetic divergence. Therefore, the aim of the present study was to assess genetic diversity among 13 accessions of $C$. argentea from the same population maintained in the active germplasm bank of Embrapa Meio-Norte using inter-simple sequence repeat (ISSR) markers. Genetic similarities between C. argentea accessions were estimated from Jaccard coefficients, and a dendrogram was constructed using the unweighted pair group method with arithmetic average (UPGMA). The set of 15 primers selected for ISSR analysis generated a total of 313 loci of which $79.23 \%$ were polymorphic. The mean number of bands per primer was 20.87 , and the amplicons
\end{abstract}


ranged from 280 to $3000 \mathrm{bp}$ in size. Primers UBC834 and UBC827 generated the largest number of polymorphic loci and exhibited 90.91 and $100 \%$ polymorphism, respectively. The coefficients of genetic similarity among accessions varied between 0.49 and 0.73 . UPGMA cluster analysis allowed the identification of four genotypic groups and demonstrated the existence of considerable variability within the collection. Potential progenitors were selected that would offer good possibilities of obtaining unusual and favorable combinations of genes in a plant breeding program.

Key words: Molecular characterization; Forage crop; Genetic diversity; ISSR markers

\section{INTRODUCTION}

In the semiarid north-eastern region of Brazil, the low amount and irregular distribution of rainfall lead to significant levels of soil water deficits in the dry season when temperatures rise and evapotranspiration increases. During this period, the availability of quality forage is severely limited and supplementation of fodder is crucial in animal farming to obtain acceptable productivity (Andrade et al., 2010). Increasing the resistance of forage crops to climatic and abiotic stress would help to alleviate the shortage in supply, a goal that could be achieved by evaluating the intraand inter-specific variability of native forages and crossing the most divergent genotypes to obtain elite hybrids with superior traits.

Cratylia argentea (Desv.) Kuntze, commonly known as Camaratuba, is a deep-rooting perennial legume found exclusively in South America, particularly in Brazil, Bolivia, and Peru (Argel and Lascano, 1998). This plant is well adapted to acid soils, and shows high productivity and nutritional value. Moreover, the shrub is drought-tolerant, has the capacity to retain green leaves, and exhibits regrowth under arid conditions, characteristics that would favor its use as a dry season forage supplement for cattle and sheep (Lascano et al., 2002).

Forage legumes can improve animal performance because their nutritional properties are superior to those of grasses and they improve the nitrogen content of the soil through symbiosis with nitrogen-fixing bacteria. Such legumes can contribute to the supply of forage over protracted periods and, thereby, reduce the effects of feed discontinuity for livestock associated with the exclusive use of grass pastures (Barcellos et al., 2008).

The genetic improvement of forage crops gives rise to cultivars with improved productivity, enhanced tolerance to biotic and abiotic stresses, and better feed conversion efficiency (Jank et al., 2011). The use of this technology has resulted in the improvement of tropical forages such as BRS Campo Grande (Stylosanthes spp.) and BRS Mandarim (Cajanus cajan), but many other genera and species could also be genetically manipulated (Euclides et al., 2010).

An important step during plant improvement is the molecular characterization of the species, since knowledge of genetic similarities facilitates the identification of heterotic groups and allows the selection of the most divergent parents for crossing (Bonato et al., 2006). Information on genetic variability among specimens within a collection is of critical importance when dealing with a species such as $C$. argentea that has yet to be domesticated (Kamada, 2006). In this context, molecular markers are of particular value because they reveal differences in plant DNA that are independent of environmental factors. The inter-simple sequence repeat (ISSR) technique is straightforward, rapid, efficient, and reproducible, and involves amplification of DNA segments 
between two identical microsatellite regions oriented using the polymerase chain reaction (PCR) (Reddy et al., 2002). In the present study, ISSR markers were employed within a plant improvement and conservation program to determine the genetic diversity among accessions of $C$. argentea maintained at the active germplasm bank of Embrapa Meio-Norte (Teresina, PI, Brazil).

\section{MATERIAL AND METHODS}

\section{Plant material}

Young leaves were harvested from $13 \mathrm{C}$. argentea accessions (C1, C2, C3, C5, C6, C7, $\mathrm{C} 8, \mathrm{C} 9, \mathrm{C} 10, \mathrm{C} 11, \mathrm{C} 12, \mathrm{C} 13$ and C14), all of which originated from Codó, MA, Brazil, and had been maintained at the Germplasm Bank of Native Forages of Embrapa Meio-Norte. Samples, stored in labeled plastic bags and cooled over ice, were transported to the Laboratory of Biotechnology and Molecular Biology, Embrapa Meio-Norte, and kept at $-20^{\circ} \mathrm{C}$ until analysis.

\section{DNA extraction and PCR amplification}

Genomic DNA was extracted from the leaves $(0.1 \mathrm{~g})$ of each accession using Qiagen (Venlo, Netherlands) kits following the manufacturer protocol. Aliquots of extracted DNA were subjected to electrophoresis on $0.8 \%$ agarose gel in Tris-borate-EDTA (0.5X TBE) buffer and subsequently stained with GelRed ${ }^{\mathrm{TM}}$ (1:1000; Biotium, Hayward, CA, USA). The quantity and quality of extracted DNA were determined by comparing with $\lambda$ DNA standards (100 ng) and using a NanoDrop 2000 spectrophotometer (ThermoFisher Scientific, Waltham, MA, USA).

DNA samples were amplified using 37 primers developed by the University of British Columbia, Vancouver, Canada. The PCR mixture contained 1.0X buffer (10 mM Tris- $\mathrm{HCl}, 50 \mathrm{mM}$ $\mathrm{KCl}, 1.5 \mathrm{mM} \mathrm{MgCl}$; New England Biolabs, Ipswich, MA, USA), $0.5 \mu \mathrm{L}$ DNA template $(7.0 \mathrm{ng} / \mu \mathrm{L})$, $1.0 \mathrm{mM}$ dNTPs, $0.3 \mu \mathrm{M}$ primer, $0.5 \mathrm{U}$ Taq DNA polymerase (New England Biolabs) and ultrapure distilled water to a final volume of $10 \mu \mathrm{L}$. Amplification reactions were carried out in a Veriti 96Well Thermal Cycler (Applied Biosystems, Foster City, CA, USA) under the following conditions: initial denaturation for $90 \mathrm{~s}$ at $94^{\circ} \mathrm{C}, 40$ cycles each comprising denaturation for $40 \mathrm{~s}$ at $94^{\circ} \mathrm{C}$, annealing for $45 \mathrm{~s}$ at the temperature specified in Table 1, extension for 2 min at $72^{\circ} \mathrm{C}$, and final extension for $7 \mathrm{~min}$ at $72^{\circ} \mathrm{C}$. The resulting amplicons were separated by electrophoresis on $1.5 \%$ agarose gel in $0.5 \mathrm{X}$ TBE buffer for $6 \mathrm{~h}$ at $110 \mathrm{~V}$, stained with GelRed (1:1000), visualized under a UV transilluminator, and subsequently photographed. The sizes of amplicons were estimated by comparison with a 1-kb DNA ladder (Invitrogen, Life Technologies do Brasil, São Paulo, SP, Brazil).

\section{Statistical analysis}

Analyses were performed with the aid of the PAST program version 1.34 (Hammer et al., 2001). Fifteen of the 37 primers tested were selected based on greater resolution of amplicons and higher levels of polymorphism, and these were employed in subsequent analyses. On the basis that each amplicon represented a single character, a binary matrix was created in which 1 indicated the presence and 0 indicated the absence of a specific band. From this matrix, genetic similarities between accessions of $C$. argentea were estimated using Jaccard coefficients, and a dendrogram was constructed using the unweighted pair group method with arithmetic average 
(UPGMA) clustering technique. The cophenetic correlation coefficient $(r)$ and the bootstrap confidence index were calculated from the binary matrix of amplified fragments and the dendrogram after 1000 permutations.

\section{RESULTS}

The 15 primers selected for ISSR analysis of $C$. argentea accessions generated 313 loci of which 248 (79.23\%) were polymorphic (Table 1). The sizes of the amplicons ranged from 280 to $3000 \mathrm{bp}$. The mean number of bands per primer was 20.87, with primers UBC834 and UBC848 generating the highest (33) and UBC808 the lowest (7) numbers. Primers UBC834 and UBC827 generated the largest number of polymorphic loci, and exhibited 90.91 and 100\% polymorphism (Figure 1), respectively.

Table 1. ISSR markers used to amplify genomic DNA from 13 accessions of Cratylia argentea (Fabaceae) in the active germplasm bank of Embrapa Meio-Norte.

\begin{tabular}{|c|c|c|c|c|}
\hline \multirow[t]{2}{*}{ Primer } & \multirow[t]{2}{*}{ Sequence $5^{\prime}-3^{\prime a}$} & \multirow[t]{2}{*}{$\mathrm{Ta}\left({ }^{\circ} \mathrm{C}\right)^{\mathrm{b}}$} & \multicolumn{2}{|c|}{ Number of amplified bands } \\
\hline & & & Total & Polymorphic \\
\hline UBC 808 & AGA GAG AGA GAG AGA GC & 50 & 7 & 6 \\
\hline UBC 810 & GAG AGA GAG AGA GAG AT & 52 & 19 & 14 \\
\hline UBC 811 & GAG AGA GAG AGA GAG AC & 50 & 27 & 22 \\
\hline UBC 812 & GAG AGA GAG AGA GAG AA & 50 & 17 & 8 \\
\hline UBC 818 & CAC ACA CAC ACA CAC AG & 49 & 8 & 5 \\
\hline UBC 827 & ACA CAC ACA CAC ACA CG & 60 & 30 & 30 \\
\hline UBC 830 & TGT GTC TGT GTC TGT GG & 50 & 8 & 6 \\
\hline UBC 834 & AGA GAG AGA GAG AGA GYT & 54 & 33 & 30 \\
\hline UBC 835 & AGA GAG AGA GAG AGA GYC & 50 & 30 & 25 \\
\hline UBC 836 & AGA GAG AGA GAG AGA GYA & 54 & 25 & 23 \\
\hline UBC 840 & GAG AGA GAG AGA GAG AYT & 48 & 22 & 20 \\
\hline UBC 842 & GAG AGA GAG AGA GAG AYG & 52 & 14 & 10 \\
\hline UBC 848 & CAC ACA CAC ACA CAC ARG & 50 & 33 & 25 \\
\hline UBC 878 & GGA TGG ATG GAT GGA T & 48 & 18 & 12 \\
\hline UBC 886 & VDV CTC TCT СTC TCT СT & 50 & 22 & 12 \\
\hline Total & & & 313 & 248 \\
\hline
\end{tabular}

${ }^{\mathrm{a} Y}=\mathrm{C}, \mathrm{T} ; \mathrm{D}=\mathrm{A}, \mathrm{G}, \mathrm{T} ; \mathrm{V}=\mathrm{A}, \mathrm{C}, \mathrm{G}$ and $\mathrm{R}=\mathrm{A}, \mathrm{G} \cdot{ }^{\mathrm{b}} \mathrm{Ta}=$ annealing temperature.

Primer 827

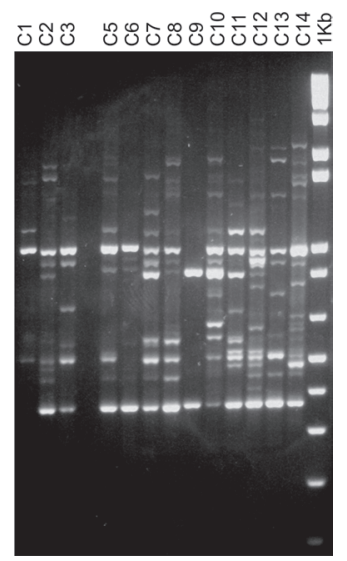

Figure 1. Electrophoretic profiles of ISSR amplifications generated by primer 827 with DNA samples derived from the 13 accessions of Cratylia argentea (Fabaceae) in the active germplasm bank of Embrapa Meio-Norte. 
The genetic similarity matrix revealed variability among the $C$. argentea accessions with Jaccard coefficients ranging from 0.49 to 0.73 (Table 2). Pairwise comparison of individual accessions revealed that $\mathrm{C} 12$ and $\mathrm{C} 13$ showed the highest coefficient of genetic similarity $(0.73)$, while the lowest was observed between C6 and C9 (0.49). The calculated value of $r$ was 0.87 , signifying that UPGMA clustering had introduced no significant distortion and that the dendrogram was a true representation of the original data.

Table 2. Jaccard coefficients showing the genetic similarities between the 13 accessions of Cratylia argentea (Fabaceae) in the active germplasm bank of Embrapa Meio-Norte.

\begin{tabular}{|c|c|c|c|c|c|c|c|c|c|c|c|c|c|}
\hline & C1 & $\mathrm{C} 2$ & C3 & C5 & C6 & C7 & C8 & C9 & C10 & C11 & C12 & $\mathrm{C} 13$ & C14 \\
\hline C1 & 1 & & & & & & & & & & & & \\
\hline C2 & 0.57 & 1 & & & & & & & & & & & \\
\hline C3 & 0.70 & 0.57 & 1 & & & & & & & & & & \\
\hline C5 & 0.65 & 0.62 & 0.60 & 1 & & & & & & & & & \\
\hline C6 & 0.50 & 0.55 & 0.52 & 0.58 & 1 & & & & & & & & \\
\hline C7 & 0.57 & 0.59 & 0.59 & 0.63 & 0.53 & 1 & & & & & & & \\
\hline C8 & 0.60 & 0.58 & 0.59 & 0.68 & 0.56 & 0.72 & 1 & & & & & & \\
\hline C9 & 0.55 & 0.53 & 0.57 & 0.57 & 0.49 & 0.58 & 0.58 & 1 & & & & & \\
\hline $\mathrm{C} 10$ & 0.58 & 0.54 & 0.60 & 0.63 & 0.52 & 0.57 & 0.60 & 0.59 & 1 & & & & \\
\hline C11 & 0.61 & 0.53 & 0.62 & 0.65 & 0.56 & 0.58 & 0.64 & 0.57 & 0.66 & 1 & & & \\
\hline C12 & 0.59 & 0.53 & 0.59 & 0.61 & 0.53 & 0.58 & 0.57 & 0.56 & 0.65 & 0.61 & 1 & & \\
\hline $\mathrm{C} 13$ & 0.57 & 0.53 & 0.57 & 0.61 & 0.53 & 0.57 & 0.57 & 0.54 & 0.65 & 0.63 & 0.73 & 1 & \\
\hline C14 & 0.58 & 0.60 & 0.59 & 0.64 & 0.57 & 0.63 & 0.62 & 0.54 & 0.65 & 0.68 & 0.66 & 0.62 & 1 \\
\hline
\end{tabular}

The average coefficient of similarity considering all of the studied loci was 0.59 , which was taken as the cut-off point in the dendrogram displayed in Figure 2. In this manner, the data obtained from ISSR analysis allowed the identification of four genotype groups. Groups 1, 3, and 4 comprised one accession each, namely $\mathrm{C} 9, \mathrm{C} 2$, and $\mathrm{C} 6$ with coefficients of $0.56,0.56$, and 0.54 , respectively. Group 2, containing the accessions C1, C3, C5, C7, C8, C10, C11, C12, C13, and C14 with an average similarity coefficient of 0.62 , could be subdivided into three subgroups as follows: subgroup 1 (C1 and C3), subgroup 2 (C5, C7, and C8), and subgroup 3 (C10, C11, C12, C13, and C14). Bootstrap confidence indices confirmed the consistency of the nodes and the reliability of the data.

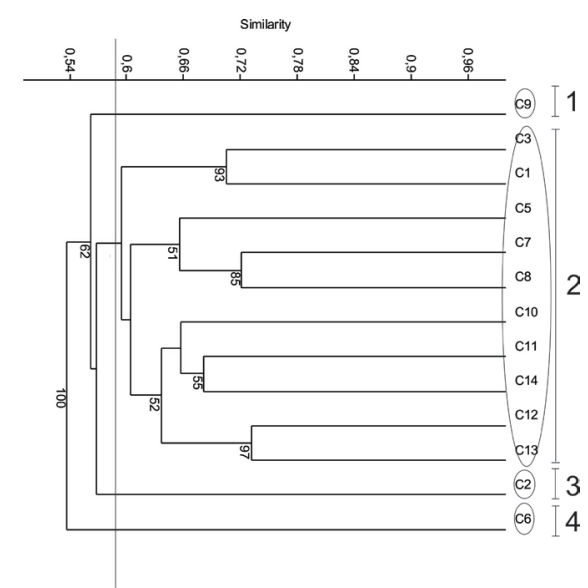

Figure 2. UPGMA dendrogram based on the 15 selected ISSR polymorphic markers showing similarity relationships between 13 accessions of Cratylia argentea (Fabaceae) in the active germplasm bank of Embrapa Meio-Norte. (Bootstrap values $>50 \%$ are shown). 


\section{DISCUSSION}

The efficiency of primers used to estimate the genetic diversity of a population is assessed by the number of polymorphic loci amplified. The ISSR primers employed in the present study afforded $79.23 \%$ polymorphism and, therefore, could be considered very efficient at determining the variability in $C$. argentea. The level of polymorphism reported herein is similar to values obtained for other leguminous species such as Vigna mungo (Kanimozhi et al., 2009; Karuppanapandian et al., 2010), Arachis hypogaea (Mondal et al., 2009), and Caragana microphylla (Huang et al., 2013), but higher than those reported by Souframanien and Gopalakrishna (2004) for V. mungo (54.5\%) and by Muthusamy et al. (2008) for V. umbellata (61.78\%).

Following ISSR analysis of the genetic relationships between $V$. unguiculata subspecies, V. radiate, and V. mungo, Tantasawat et al. (2010) reported that the mean number of bands per primer was 19.5 and that the sizes of amplified fragments varied from 200 to $3000 \mathrm{bp}$, which are similar to the values reported herein. On the other hand, the mean number of bands per primer attained in the present study was higher than those generated with V. unguiculata (8.6 bands/ primer; Ghalmi et al., 2010) and V. amoena (8.1 bands/primer; Liu et al., 2013), while the amplicons derived from $C$. argentea were larger than those obtained from Astragalus nitidiflorus (300-1500 bp; Vicente et al., 2011) and Derris trifoliata (250-2000 bp; Wu et al., 2012).

Although all of the $C$. argentea accessions in the active germplasm bank at Embrapa Meio-Norte originated from the same location, three of the identified clusters contained single accessions indicating the existence of considerable diversity, which could be used in a plant improvement program. Additionally, the coefficients of genetic similarity obtained for the accessions of C. argentea were within the limits observed for Medicago sp. (0.26-0.76; Xavier et al., 2011) and Cyamopsis tetragonoloba (0.20-0.88; Sharma et al., 2014).

Bystricky et al. (2010) determined that the gametes of C. argentea flowers were mainly self-incompatible and that successful pollination was limited in the absence of pollen from other plants. This type of reproductive mechanism explains why variability exists within the accessions, since cross-pollination permits the recombination of genes from different plants and the emergence of new combinations that do not appear in the progenitors.

Crossing highly divergent accessions is a strategy usually employed in plant improvement programs, which aims to obtain a greater value hybrid. Identification of individuals with the highest level of genetic divergence facilitates the selection of appropriate parents for such crosses, since the larger the divergence between progenitors, the greater the segregation of genes in the hybrid lineages (Franco et al., 2001). From the results presented herein, it would appear that crosses between C6 and C9, C1, and C6, C3 and C6, C6 and C10, C6 and C7, and others, would offer good possibilities of obtaining unusual and favorable combinations of genes.

The present study has highlighted the importance of maintaining and amplifying accessions of $C$. argentea in the active germplasm bank of Embrapa Meio-Norte, since the genetic diversity among accessions could be exploited in future programs aimed at breeding genotypes and forage hybrids with greater productivity, nutritional value, and resistance to drought conditions.

\section{ACKNOWLEDGMENTS}

The authors wish to thank Programa de Fortalecimento e Crescimento da Embrapa (PAC) for financial support to the study. 


\section{REFERENCES}

Andrade AP, Costa RG, Santos EM and Silva DS (2010). Produção animal no semiárido: o desafio de disponibilizar forragem em quantidade e com qualidade, na estação seca. Tecnol. Cienc. Agropec. 4: 1-14.

Argel PJ and Lascano CE (1998). Cratylia argentea (Desvaux) O. Kuntze: Una nueva leguminosa arbustiva para suelos ácidos en zonas subhúmedas tropicales. Pasturas Trop. 20: 37-43.

Barcellos AO, Ramos AKB, Vilela L and Martha Junior GB (2008). Sustentabilidade da produção animal baseada em pastagens consorciadas e no emprego de leguminosas exclusivas, na forma de banco de proteína, nos trópicos brasileiros. $R$. Bras. Zootec. 37: 51-67.

Bonato ALV, Calvo ES, Geraldi IO and Arias CAA (2006). Genetic similarity among soybean (Glycine max (L) Merrill) cultivars released in Brazil using AFLP markers. Genet. Mol. Biol. 29: 692-704.

Bystricky M, Schultzekraft R and Peters M (2010). Studies on the pollination biology of the tropical forage legume shrub Cratylia argentea. Trop. Grasslands 44: 246-252.

Euclides VPB, Valle CB, Macedo MCM, Almeida RG, et al. (2010). Brazilian scientific progress in pasture research during the first decade of XXI century. Rev. Bras. Zootec. 39: 151-168.

Franco MC, Cassini STA, Oliveira VR and Tsai SM (2001). Caracterização da diversidade genética em feijão por meio de marcadores RAPD. Pesq. Agropec. Bras. 36: 381-385.

Ghalmi N, Malice M, Jacquemin JM, Ounane SM, et al. (2010). Morphological and molecular diversity within Algerian cowpea (Vigna unguiculata (L.) Walp.) landraces. Genet. Resour. Crop Evol. 57: 371-386.

Hammer $\varnothing$, Harper DAT and Ryan PD (2001). PAST: Paleontological statistics software package for education and data analysis. Paleontol. Electron. 4: 9.

Huang WD, Zhao XY, Zhao X, Lu YQ, et al. (2013). Genetic variation within the sand-fixation species Caragana microphylla (Leguminosae) in Horqin sandy land detected by inter-simple sequence repeats analysis. Biochem. Syst. Ecol. 51: 343-348.

Jank L, Resende RMS and Valle CB (2011). Breeding tropical forages. Crop Breed. Appl. Biotechnol. 11: 27-34.

Kamada T (2006). Avaliação da diversidade genética de populações de fáfia (Pfaffia glomerata (Spreng.) Pedersen) por RAPD, caracteres morfológicos e teor de beta-ecdisona. Doctoral thesis, UFV, Viçosa.

Karuppanapandian T, Wang HW, Karuppudurai T, Rajendhran, J, et al. (2010). Efficiency of RAPD and ISSR markers in assessing genetic diversity and relationships in black gram (Vigna mungo L. Hepper) varieties. Can. J. Plant Sci. 90: 443-452.

Kanimozhi M, Jayamani P and Nadarajan N (2009). Genetic diversity as assessed by ISSR markers in Blackgram (Vigna mungo (L.) Hepper). Electron. J. Plant Breed. 1: 12-17.

Lascano C, Rincón A, Plazas C, Avila P, et al. (2002). Cultivar veranera (Cratylia argentea (Desvaux) O. Kuntze). Leguminosa arbustiva de usos múltiples para zonas con períodos prolongados de sequía em Colombia. Corporación Colombiana de Investigación Agropecuaria, Villavicencio, Colombia, and Centro Internacional de Agricultura Tropical, Cali, Colombia.

Liu Y, Zhang JM, Wang XG, Liu F, et al. (2013). Genetic diversity in Vicia amoena (Fabaceae) germplasm resource in China using SRAP and ISSR markers. Biochem. Syst. Ecol. 51: 86-93.

Mondal S, Sutar SR and Badigannavar AM (2009). Assessment of genetic diversity in cultivated groundnut (Arachis hypogaea L.) with differential responses to rust and late leaf spot using ISSR markers. Indian J. Genet. 69: 219-224.

Muthusamy S, Kanagarajan S and Ponnusamy S (2008). Efficiency of RAPD and ISSR markers system in accessing genetic variation of rice bean (Vigna umbellata) landraces. Electron. J. Biotechnol. 11: 32-41.

Reddy MP, Sarla N and Siddiq EA (2002). Inter simple sequence repeat (ISSR) polymorphism and its application in plant breeding. Euphytica 128: 9-17.

Sharma P, Sharma V and Kumar V (2014). Genetic diversity analysis of cluster bean [Cyamopsis tetragonoloba (L.) Taub] genotypes using RAPD and ISSR markers. J. Agric. Sci. Technol. 16: 433-443.

Souframanien J and Gopalakrishna T (2004). A comparative analysis of genetic diversity in blackgram genotypes using RAPD and ISSR markers. Theor. Appl. Genet. 109: 1687-1693.

Tantasawat P, Trongchuen J, Prajongjai T, Seehalak W, et al. (2010). Variety identification and comparative analysis of genetic diversity in yardlong bean (Vigna unguiculata spp. sesquipedalis) using morphological characters, SSR and ISSR analysis. Sci. Hortic. 124: 204-216.

Vicente MJ, Segura F, Aguado M, Migliaro D, et al. (2011). Genetic diversity of Astragalus nitidiflorus, a critically endangered endemic of SE Spain, and implications for its conservation. Biochem. Syst. Ecol. 39: 175-182.

Wu B, Geng SL and Shu B (2012). Genetic variation and the conservation of isolated populations of Derris trifoliata (Leguminosae), a mangrove-associated vine, in southern China. Biochem. Syst. Ecol. 40: 118-125.

Xavier JR, Kumar J and Srivastava RB (2011). Characterization of genetic structure of alfalfa (Medicago sp.) from transHimalaya using RAPD and ISSR markers. African J. Biotechnol. 10: 8176-8187. 